\title{
Workplace physical activity intervention programs: costs and benefits
}

\begin{abstract}
The execution time of the Workplace Physical Activity Intervention is not clear in the literature, in which some authors recommend to organize programs with weekly duration of about 3 hours and 45 minutes. This amount of spent time makes the cost of Workplace Physical Activity Intervention greater than the possible benefits. The Workplace Physical Activity Intervention generates costs for institutions, such as the hiring of professionals, materials that will be used and the hours left to perform physical exercises. However, this expense may be lower if the company opts for Workplace Physical Activity Intervention proposals that are shorter in duration but prove their benefits to employees and the contracting institution. From this perspective, the purpose of this manuscript is to discuss the cost and benefit of the traditional Workplace Physical Activity Intervention and the proposal of Laux.
\end{abstract}

Volume I Issue 4 - 2017

\section{Rafael Cunha Laux}

Departamento de Educação Física, Universidade do Oeste de Santa Catarina, Brazil

Correspondence: Rafael Cunha Laux, Departamento de Educação Física, Universidade do Oeste de Santa Catarina, Santa Catarina, Brazil, Tel +55(49) 3319-2600,

Email rafael.laux@unoesc.edu.br

Received: June 02, 2017| Published: August 16, 2017

Keywords: workplace, physical activity, health, life quality

\section{Introduction}

Technological advances transform people's lives and the way they relate to work. This excess of connectivity associated with the speed of communication of modernity causes an excessively increasing of hours at work bringing some physical and mental harms. ${ }^{1}$ These occupational diseases can be aggravated in administrative services, in which employees have work activities with sedentary tasks, such as sitting for many continuous hours. ${ }^{2}$

In an attempt to improve the quality of life, health and increase productivity emerges primary intervention programs for worker health. ${ }^{3}$ These programs introduced into the work environment aim at combating smoking and preventing work-related and sedentary diseases. $^{4}$

Workplace Physical Activity Intervention stands out for the prevention of the diseases in the skeletal muscle system (muscles, joints and bones) and the decrease of the stress. In Brazil, this kind of program is known as Labor Gymnastics. ${ }^{5,6}$ Despite the numerous studies using these programs, there are still many disagreements over the execution time and number of weekly sessions. ${ }^{6,7}$ According to Branco $^{7}$ the ideal would be to apply this type of program with sessions of 15 minutes, three times a day, every day of the week, however, if a quick analysis is done, it is observed that this generates an average expenditure of 3 Hours and 45 minutes without considering dislocating time of the employees for the execution of the exercises.

The traditional method has proven benefits, such as decreasing the intensity and frequency of muscle pain and improving posture in the sitting position ${ }^{8}$ and decreasing absenteeism and increasing productivity ${ }^{9}$ but the main issue is cost-benefit, as new intervention proposals $^{6}$ also have benefits such as the reduction of medical attestations ${ }^{5}$ improvement in mood and reaction time. ${ }^{6}$ In view of this discussion about the ideal time and the time savings in the realization of these programs, the purpose of this manuscript arises, it is to discuss the cost and benefit of the traditional Workplace Physical Activity Intervention and the proposal of Laux. ${ }^{6}$

\section{Comparison of the traditional workplace physical activity intervention and laux proposal (20|6)}

The implementation of Workplace Physical Activity Intervention generates expenses for the company, in addition to the expenses with the professionals involved and the purchase of material, the institution has costs with the execution of the project. In the ideal model of implementation of the program addressed by $\mathrm{Branco}^{7}$ the duration of each session should be 15 minutes, in three different periods - at the beginning of the work, preparatory gymnastics; In the middle of the work day, compensatory gymnastics; and at the end of the work day, relaxation gymnastics. However, this method of application generates a weekly cost referring to 3 hours and 45 minutes of the total production of the company, not including the displacement of employees. Pereira ${ }^{8} \&$ Figueiredo, Mont'alvão ${ }^{9}$ emphasize that these sessions should take between 10 and 15 minutes, three times a day.

It is not the purpose of this article to calculate the company's spent money, but rather to emphasize the time spent and to point out methods of classes that bring benefits without causing a high cost of application, and its benefits to employees and companies. According to the proposed Workplace Physical Activity Intervention Laux ${ }^{6}$ these programs should last between 8 and 15 minutes per daily session, without indicating the weekly amount required. The study by Laux et al. ${ }^{5}$ with workers from an industrial waste company, with 10-minute sessions twice a week, using the Laux proposa ${ }^{6}$ observed a decrease of $51.52 \%$ in the total of medical attestations, in which there was a decrease of $43.48 \%$ in medical attestations by systemic diseases and $55.56 \%$ in medical attestations by musculoskeletal diseases. With the application of this program with the same duration per session, three times a week, there was an improvement in the negative aspects of mood (depression, fatigue, mental confusion, tension and anger) and the time of simple reaction and the time of choice. ${ }^{6}$

The studies of Laux et al. ${ }^{5}$ prove that the benefits of Workplace Physical Activity Intervention occur in programs with short sessions, 
with two or three applications per week. Considering that these interventions had a weekly duration of between 20 and 30 minutes and improved the number of medical attestations and the cognitive aspects related to mood and speed of response, but with a reduction of at least 3 hours and 15 minutes a week than the recommended by other authors, ${ }^{7}$ the institutions may have a less time expenditure of about $86.67 \%$.

The Workplace Physical Activity Intervention showed several benefits, whether cognitive ${ }^{6}$ physical $^{5,10,11}$ or emotional ${ }^{6}$ however, some methods of application are more economical in the time used in the application of the exercise program. Other methods of promotion of physical activity in the work environment are highlighted, but it is necessary to emphasize that in the majority there is no direct intervention with physical exercise, as for example in the study by McEachan et al. ${ }^{12}$ who used physical activity awareness material, or in the research of Cocker, Bourdeaudhuij et al. ${ }^{13}$ who used pedometers and the intervention was by established goals, in which the subject would have to reach the weekly or monthly steps goal. Another factor that is observed in research is that the intervention with physical activity is out of the work environment, as in the study of Edmunds ${ }^{14}$ first disfiguring the type of intervention and reducing the level of participation in the program, since workers need to go to another environment to carry out the activity.

\section{Conclusion}

In discussing the cost and benefit of the traditional Workplace Physical Activity Intervention and the proposal of Laux (2016), it is important to emphasize the importance of opting for proposals of programs that have obtained relevant results in aspects related to presence and work performance, such as the reduction of medical attestations and cognitive improvement, in addition to the savings of $86.67 \%$ in the execution time of the physical exercise program. It is emphasized that other studies should be carried out in order to prove other possible benefits of this program, in addition to the comparison with other methods of Workplace Physical Activity Intervention.

\section{Acknowledgements}

None

\section{Conflict of interest}

The author declares no conflict of interest.

\section{References}

1. Mezzomo SP, Contreira AR, Corazza ST. Os efeitos da ginástica laboral sobre as habilidades básicas de funcionários de setores administrativos. Revista Brasileira de Ciências da Saúde. 2010;8(25):6-13.
2. Vargas LM, Pilatti LA, Gutierrez G. Inatividade física e fatores associados: um estudo com trabalhadores do setor metalomecânico do município de Ponta Grossa -PR. Rev Bras Ativ Fis Saúde. 2013;18(1):31-42.

3. Baicker K, Cutler D, Song Z. Workplace Wellness Programs Can Generate Savings. Health Aff. 2010;29(2):304-311.

4. Martins CO, Michels G. Programas de promoção da saúde do trabalhador: exemplos de sucesso. Brazilian Journal of Kinanthropometry and Human Performance. 2003;5(1):85-90.

5. Laux RC, Pagliari P, Effting Junior JV, et al. Programa de Ginástica Laboral e a Redução de Atestados Médicos. Ciencia \& trabajo. 2016;18(56):130-133.

6. Laux RC. Efeitos da intervenção com exercícios físicos no ambiente de trabalho sobre o tempo de reação e o humor. Master's Dissertation in Physical Education, Universidade Federal de Santa Maria, Brazil; 2016. $76 \mathrm{p}$.

7. Branco AE. Ginástica Laboral: Prerrogativa do Profissional de Educação Física 1st ed. CONFEF, Rio de Janeiro, Brazil; 2015. 64 p.

8. Pereira CCDA. Excelência técnica dos programas de ginástica laboral. Phorte, São Paulo, Brazil; 2013. 168 p.

9. Figueiredo F, Mont'Alvão C .Ginástica laboral e ergonomia 2nd ed. Sprint, Rio de Janeiro: Brazil; 2008. 192 p.

10. Candotti CT, Stroschein R, Noll M . Efeitos da ginástica laboral na dor nas costas e nos hábitos posturais adotados no ambiente de trabalho. Revista Brasileira de Ciências do Esporte. 2011;33(3):699-714.

11. Addley K, Mcquillan P, Ruddle M. Creating healthy workplaces in Northern Ireland: evaluation of a lifestyle and physical activity assessment programme. Occup Med. 2001;51(7):439-449.

12. McEachan RRC, Lawton RJ, Jackson J, et al. Testing a workplace physical activity intervention: a cluster randomized controlled trial, International Journal of Behavioral Nutrition and Physical Activity. 2011;8(29):1-12.

13. Cocker KA, Bourdeaudhuij IM, Cardon GM. The effect of a multistrategy workplace physical activity intervention promoting pedometer use and step count increase. Health Educ Res. 2009;25(4):608-619.

14. Edmunds $\mathrm{S}$, Clow $\mathrm{A}$. The role of peer physical activity champions in the workplace: a qualitative study. Perspect Public Health. 2015;20(10):110 